MATEC Web of Conferences 46, 05002 (2016)

DOI: $10.1051 /$ matecconf $/ 20164605002$

(C) Owned by the authors, published by EDP Sciences, 2016

\title{
Means of regulating combustible materials and products in external walls
}

\author{
Esko Mikkola \\ KK-Fireconsult Ltd., FI-02240 Espoo, Finland
}

\begin{abstract}
This report presents proposals for defining means of regulating the use of combustible materials and products in external walls. Required protections are based on the quantities of fire loads and their contribution to fire development. The study is based on life safety and protection of property priorities taking into account reaction to fire classes related to different types of fire loads and fire compartmentation requirements of the adjacent spaces of concern.

The proposals include the following main principles in relation to fire-separation requirements: In case of internal fire exposure the protective structure for combustible building parts needs to meet at least half of the fire-separating requirement for the compartment of concern. In case of external fire exposure the protection time requirement can be 15 minutes less than for the internal protection. The proposals are applicable for residential buildings and offices. In case of buildings with longer evacuation times more stringent requirement levels may be considered.

For verification of protection performance of fire loads it is proposed to use existing standardized test methods (fire protection ability (K classes) and fire-separating function (EI classes) validated methods of calculation and/or large scale fire testing.
\end{abstract}

\section{INTRODUCTION}

More stringent energy efficiency requirements for buildings have increased insulation layer thicknesses and the use of combustible insulation materials in external walls. Other changes during the last decades have been at least the following: The quantity and quality (more flammable items) of movable fire loads have changed, new construction products have entered to the market and new structural and architectural solutions have been developed. The main topic of this paper is to assess the contribution of thermal insulation materials (and other building materials within external walls) to the fire spread and required means of protection.

In regulations restrictions for use of combustible materials may be used or when such materials and products are allowed, minimum requirements of protection can be defined or fire performance may be verified by using large scale fire testing.

A prerequisite for the assumption that combustible building materials/products need not to be taken into account in fire development (and in consequences of fire spread), is that the fire load of concern will not contribute to fire in a certain time (e.g. time needed for safe evacuation). This means that combustible products usually need to be covered by protective layers and the protective performance is related to the assumed fire exposures of concern.

This is an Open Access article distributed under the terms of the Creative Commons Attribution License 2.0, which permits unrestricted use, distribution, and reproduction in any medium, provided the original work is properly cited. 


\section{FIRE LOADS AND THEIR CONTRIBUTION TO FIRE}

Fixed fire loads within building structures need not to be assumed to contribute to fire in all cases (e.g. within a defined time related to use of the building) or it can be assumed that the fire load burns only partly, if the fire load can be protected in a reliable manner. There are different protection methods available. Coverings (=products/boards having fire protection ability) are aimed to protect materials behind the covering from fire for specified times, such as 10 or 30 minutes. Similar protective effects can be achieved by using fire-separating building elements (e.g., EI15, EI30, EI60, etc.). Fire loads can be protected from fire also by preventing or limiting the fire by using automatic extinguishing systems.

It can be assumed that combustible building materials/products need not to be taken into account in any case in fire, when the fire load of concern will not contribute to fire development during the whole fire duration (including cooling phase). In practice, this can lead e.g. to the following interpretations:

- If the fire load is at maximum $600 \mathrm{MJ} / \mathrm{m}^{2}$, then $60 \mathrm{~min}$ protection time (according to standard fire exposure curve) is always sufficient (even when there is no automatic extinguishing).

- The protection can also consist of a combination of passive (protection board) and active (automatic extinguishing) methods.

On the other hand, as an example the Finnish fire regulations [1] use 10 minutes fire protection time in 12 floor buildings assuming that a sufficient delay in the contribution to fire development of the protected fire load is reached. In this case, the emphasis is in life safety and property protection is having a lower priority (because total losses and risks to the neighborhood are lower than in case of higher buildings).

The higher the buildings are, the more important it is to limit the amount of fixed fire load contributing to fire. This is not only because of life safety (long evacuation times) but also because total effective fire loads which are higher than the design values can lead to collapse of the building.

Fire load consists of moveable property and fixed fire load in building structures. From regulatory point of view these two parts can be described as follows:

- Movable property as a fire load:

- Furniture, fixtures, equipment, storage of goods, etc.

- Mostly not regulated; room size and heat of combustion values of materials give the limits.

- Fixed fire loads within building materials and structures:

- Surface linings, thermal insulations and other building products.

- Load-bearing structures.

- Building regulations give restrictions regarding combustibility (fire load) in load-bearing structures and thermal insulations depending on fire class of the building, number of storeys and use of the building.

\section{SIGNIFICANCE OF THERMAL INSULATIONS IN FIRE LOADS}

Figure 1 provides a summary of fire load changes concerning thermal insulations in external walls when normalized per apartment floor area in Finland [2]. The illustration shows the extreme limiting cases where either one of the apartment walls is an outer wall or three walls are outer walls.

In EPS and PIR insulated buildings the increase in total fire load (per floor area) caused by exterior walls between years 1976-2010 was $10 \pm 3 \%$ assuming that all of the fire load could contribute to fire. Corresponding increase in case of stone wool insulation has been less than $1.7 \%$. 


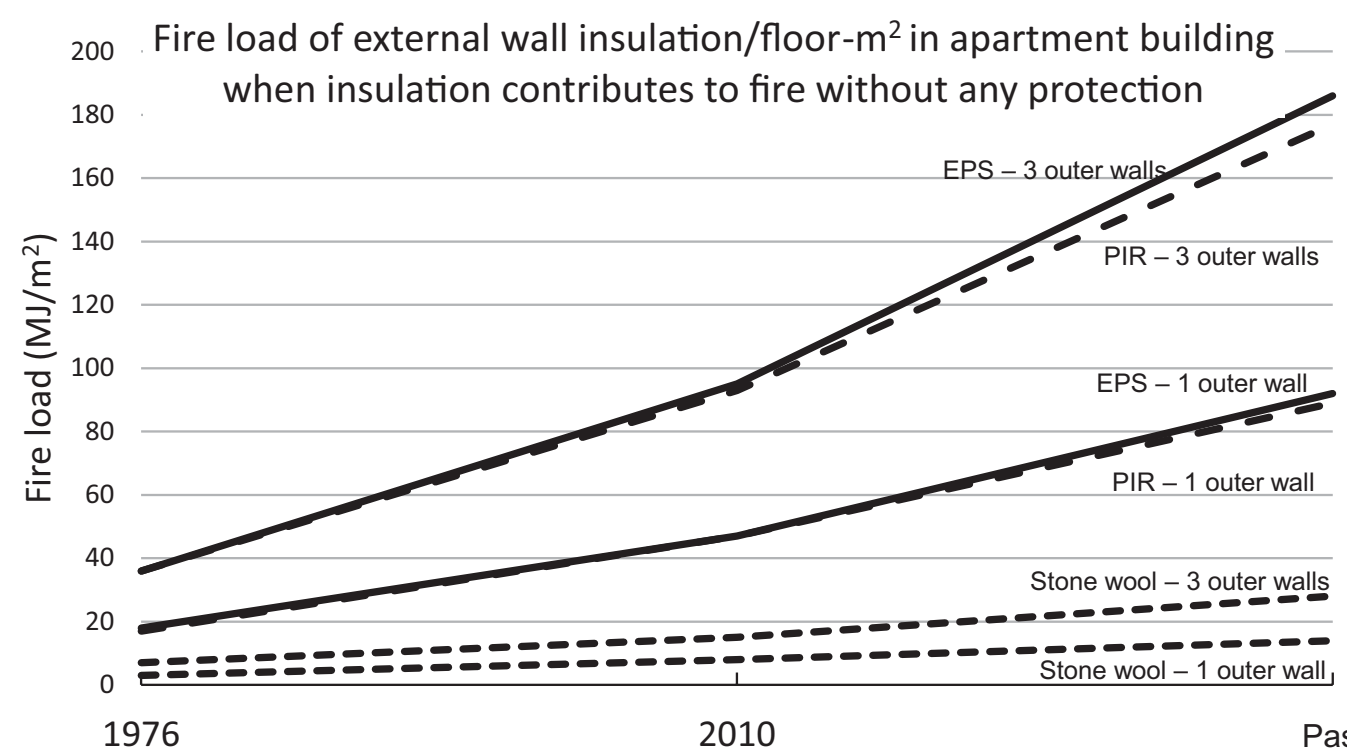

Figure 1. Changes in fire loads of external wall thermal insulations normalized per floor area in cases where one or three of walls of an apartment are outer walls (Case Finland; Passive refers to possible future requirements).

Table 1. Estimated values of fire load and rate of heat release for $200 \mathrm{~mm}$ thick thermal insulation materials without any protection in different reaction to fire classes.

\begin{tabular}{|l|c|c|c|}
\hline $\begin{array}{l}\text { Fire class and } \\
\text { Density of insulation }\end{array}$ & Fire load $\left(\mathrm{MJ} / \mathrm{m}^{2}\right)$ & $\begin{array}{c}\text { Rate of heat release }\left(\mathrm{kW} / \mathrm{m}^{2}\right) \\
900 \mathrm{~s} \text { mean value }\end{array}$ & $\begin{array}{c}\text { Heat of combustion } \\
\text { estimates }\end{array}$ \\
\hline $\mathrm{A} 2-\mathrm{s} 1, \mathrm{~d} 0 ; 50-120 \mathrm{~kg} / \mathrm{m}^{3}$ & $30-70$ & $<20$ & A2 limit $=3 \mathrm{MJ} / \mathrm{kg}$ \\
\hline $\mathrm{B}-\mathrm{s} 1, \mathrm{~d} 0 ; 30-50 \mathrm{~kg} / \mathrm{m}^{3}$ & $60-200$ & $<100[3]$ & $6-20 \mathrm{MJ} / \mathrm{kg}$ \\
\hline $\mathrm{D}-\mathrm{s} 2, \mathrm{~d} 2 ; 25-50 \mathrm{~kg} / \mathrm{m}^{3}$ & $100-200$ & $<250[3]$ & $10-20 \mathrm{MJ} / \mathrm{kg}$ \\
\hline E-F; $15-20 \mathrm{~kg} / \mathrm{m}^{3}$ & $100-150[4]$ & $200-500[4]$ & $30-40 \mathrm{MJ} / \mathrm{kg}$ \\
\hline
\end{tabular}

\section{FIRE PERFORMANCE AND PREVENTION OF SPREAD OF FIRE}

\subsection{Reaction to fire classes of materials and their contribution to fire}

Thermal insulations are installed on the whole area of external walls with the exception of windows, doors and other openings. In Table 1 fire load and heat release values per building envelope area are given in the case when the $200 \mathrm{~mm}$ thick thermal insulation product is without any protection. These estimated values are based on relevant parameter limit values of each reaction to fire class.

In addition to the characteristics described in Table 1, significant differences between fire performance of products arise on whether the products char or melt: in charring materials spread of fire is usually slow and the propagation of char front can be predicted, whereas in melting products voids can be created which may cause additional spread of fire.

\subsection{Protection of combustibles within building structures}

For regulatory purposes it is proposed that protection of combustible products within external walls is defined in relation to the fire exposure of concern. The assumed fire exposure can be based e.g. on internal partitioning requirement (which is related to assumed fire load) or on external fire exposure based on large flames from a window (flashover fire). 


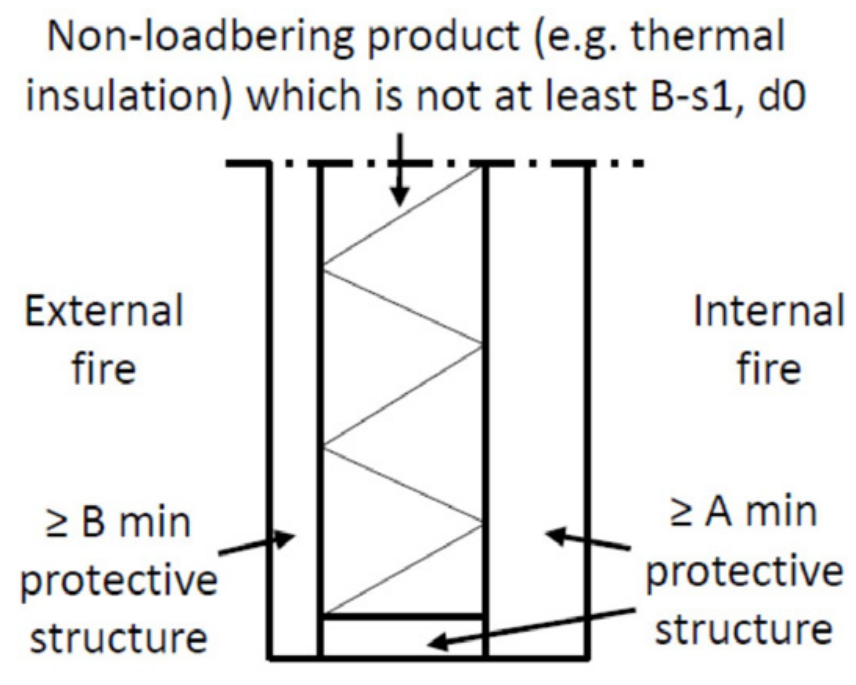

Opening, penetration

Figure 2. Protection against internal and external fire.

Main principles of the proposals in relation to internal compartmentation requirements (see Fig. 2) are:

Internal fire exposure (subject to inner surfaces and edges around openings):

- Protective structure fulfils at least half of the requirement for fire separating building elements in the space of concern.

- Applies also to protection of any ventilation gaps.

External fire exposure (subject to outer surfaces):

- Requirement for interior surfaces reduced by 15 minutes (except in case of EI30 requirement for interior spaces, reaction to fire requirements should be applied).

Note that the protection requirement against the internal fire is applicable also to edges of all windows and doors (including possible openings to ventilation gaps) as well as penetrations. Requirements for external surfaces are usually lower than for internal surfaces because of lower total fire exposures (open space and faster cooling).

The proposals are applicable for residential buildings and offices. In case of hotels, schools, day care centres and hospitals there is a need to take into account possible longer evacuation times and as a consequence more stringent requirement levels may be used.

\section{VERIFICATION OF PROTECTION METHODS OF FIRE LOADS}

For verification of protection performance levels of combustible materials and products within external walls the following options are being proposed:

A. Application of existing European test methods (fire protection ability (K classes) [5] and fireseparating function (EI classes) [6]) and calculation methods (e.g. Eurocode).

B. Large-scale facade testing - need for internationally accepted method (one test method capable of differentiating performance levels (classes) according to national needs). 
C. Case by cases assessment using performance based fire safety design.

- E.g. analysis based on in-depth temperature measurements of a wall construction in a fire resistance test.

Concerning fire-separating requirement, the protective structure shown in Fig. 2 shall fulfil the criteria given in the test method and in the classification standard either tested as a protective layer alone, or alternatively, as part of an end-use structure. In the latter case, verification of performance of the protection ability is based on measurement of insulation performance (thermocouples on the unexposed face of the protective structure), and on integrity (observation of cracks and holes in the protective structure).

\subsection{Calculation methods}

EN 1995-1-2 (Eurocode 5. Design of timber structures. Part 1-2: General. Structural fire design) [7] includes calculation methods for insulation performance for wooden boards, gypsum boards, stone wool and glass wool insulation materials. The calculation results must be associated with necessary guidance on mounting methods and sealing of joints.

Also other suitable (validated) calculation methods can also be used. The calculation method must be able to demonstrate that fire performance levels corresponding to the covering classes or fire-separating classes of concern are reached.

\section{DISCUSSION AND CONCLUSIONS}

As far as it concerns fire safety the most simple way to regulate the use of combustibles in external walls is to forbid their use according to type the building, use of the building, etc. However, this may not always lead to the best overall performance of the building. Thus use of combustibles can be allowed, but defined protective layers need to be used according to required fire performance levels taking into account both safety of life and property protection.

From the point of view of regulations, it would be desirable to use a fire load definition, which usually (in most cases) does not lead to a specific assessment of the fire load, but assumed values for fire load categories can be used. Two types of fire loads can be determined: Internal fire load of a fire compartment including movable fire load, fixed furniture and fire load within surface layers of structural elements, and protected fire load within building elements (protective performance determined according to the type of the building and fire-separating requirements).

For protection levels of fire loads within structures the following is proposed in relation to internal fire compartmentation:

Internal fire exposure (subject to inner surfaces and edges around openings):

- Protective structure fulfils at least half of the requirement (and not more than the requirement) for fire-separating building elements in the space of concern.

External fire exposure (subject to outer surfaces):

- Requirement for internal surfaces reduced by 15 minutes (except in case of EI30 requirement for interior spaces, reaction to fire requirements should be applied).

For verification of protection performance of fire loads it is proposed to use existing standardized test methods (fire protection ability (K classes) and fire-separating function (EI classes)), validated calculation methods or large-scale fire testing. 


\section{MATEC Web of Conferences}

Tuomo Rinne and Peter Grönberg are thanked on fire load analysis. The financial support of Finnisolry is gratefully acknowledged.

\section{References}

[1] E1. The national building code of Finland. Fire safety of buildings. Regulations and guide-lines 2011. Helsinki. Ministry of the Environment (In Finnish).

[2] Mikkola, Esko. Fire loads and fire safety in buildings. Part 2: Protection of fire loads within building structures. Research report. KK-Palokonsultti Oy, Espoo, 2015.

[3] Östman, Birgit; Tsantaridis, Lazaros; Mikkola, Esko; Hakkarainen, Tuula; Belloni, Kaisa; Brumer, Harry; Piispanen, Peter. 2006. Innovative eco-efficient high fire performance wood products for demanding applications. Final report for Vinnova-Tekes project InnoFIreWood. Stockholm, SP Wood Technology. 98 s. SP Swedish National Testing and Research Institute, Report 2006: 30.

[4] Mikkola, Esko; Hakkarainen, Tuula; Matala, Anna. 2013. Fire safety of EPS ETICS in resi-dential multi-storey buildings, VTT. 37 p. + app. 4 p. Research Report; VTT-R-04632-13.

[5] EN 14135. Coverings - Determination of fire protection ability. CEN 2004.

[6] EN 13501-2. Fire classification of construction products and building elements - Part 2: Classification using test data from resistance fire tests, excluding ventilation services.

[7] EN 1995-1-2. Eurocode 5. Design of timber structures. Part 1-2: General. Structural fire design. 